\title{
University branding: different roles of brand personality and satisfaction
}

\author{
Nonik Kusuma Ningrum*, Ratih Kusumawardani, Ignatius Soni Kurniawan \\ Universitas Sarjanawiyata Tamansiswa, Yogyakarta, Indonesia \\ *Corresponding author: nonik.kusumaningrum@ustjogja.ac.id
}

\begin{abstract}
This study aims to provide an integrative framework that investigates the effect of brand experience on loyalty that is mediated by brand personality and satisfaction in the context of an Indonesia's private university branding. This study applies an explanatory quantitative research method using purposive random sampling as the sampling technique. The data is collected from a total of 385 students of a private university in Yogyakarta using questionnaires. A rigorous analysis of the structural equation model is used to analyze and interpret the data. The result shows that brand experience has no direct effect on brand loyalty, however it has indirect on satisfaction and simultaneously through brand personality and satisfaction. This means that students of a private university perceived that satisfaction is the most important aspect on building loyalty. This study implies that private universities should improve students' satisfaction to gain loyalty, and consider university brand experience and brand personality in order to strengthen students' satisfaction toward the university. Building loyalty is important because it can lessen the vulnerability of university in facing competition, not only with local but also with overseas universities or branch of the world's best university to come to Indonesia in the future.
\end{abstract}

Keywords: University branding, brand experience, brand personality, satisfaction and loyalty

JEL Classification Code: M31

DOI: 10.20885/jsb.vol24.iss1.art5

\section{Introduction}

Nowadays, universities have changed from traditional to modern institutions. They start to realize the importance of a strong brand in order to differentiate themselves from competitors, thrive to gain market share and survive in the market place, attract prospective students, parents, and advisor awareness, and empowered university ability to recruit high-quality faculty members and administrators (Bennett \& Ali-Choudhury, 2009). By having a strong brand, university will be able to express prestige, reduce risk through quality and legitimacy, gaining donors, facilitate rational and emotional decision, enable alumni to have a sense of belonging as a long term university members, and help students to associate themselves with the organization and shaping their self-concept (Stephenson \& Yerger, 2014). Because it perceived as the best quality and reputation among alternatives, not vulnerable to price, and it can encourage repeat purchase (Brewer \& Zhao, 2010), at their best a strong university brand can build loyalty and maintain sustainable profitability in the long run (Pinar et al.,, 2011).

Studies on brand have massively been conducted, however, there are only limited numbers of works have been done in the scope of university branding. Most of studies on university branding focused on university's brand identification (Fazli-Salehi et al.,, 2019; Heffernan et al.,, 2018; Pinna et al.,, 2018; Foroudi et al.,, 2017, Balaji et al.,, 2016; Goi et al.,, 2014; Stephenson \& Yerger, 2014; Khanna et al.,, 2014; Kantanen, 2012; Balmer \& Liao, 2007; Kim et al.,, 2001; and Baker \& Balmer, 1997), brand equity (Herrero-Crespo et al.,, 2016; Pinar et al.,, 2014; and Mourad et al.,, 2011) and reputation (Plewa et al.,, 2016; Williams \& Omar, 2014; and Aula \& Tienari, 2011). Furthermore, in today's global market place, the university is not only facing competition in the country but also across the globe, therefore understanding university loyalty can be the key strategy to strengthen university competitive position in the market and stand out from the crowd. 
Realizing the importance of loyalty, this study aimed to explore university loyalty antecedents through a corporate branding perspective. In their study related to university loyalty, Giner \& Rillo (2016) found that loyalty can be shaped through satisfaction. This finding was in line with research conducted by Oliver (1999) and Oliver (1980) on loyalty and satisfaction. Moreover, Brakus et al., (2009) on their research found that loyalty can be directly shaped through information processing evokes by brand experience and brand-related association by brand personality. In their study, they found that brand experience can be directly and indirectly affects loyalty. Based on previous studies, this study adapted this empirical finding into the university branding context and will be the first study to conduct this framework in this field. This study intended to explain the effect of brand experience on brand loyalty directly and indirectly mediated by brand personality and satisfaction.

\section{Literature Review}

\section{Brand Experience}

There are some experience concepts proposed by the researchers. The first concept is experiential marketing. Experiential marketing considers consumers as rational and emotional person once attaining delightful experience (Schmitt, 1999). The second one is the product experience. Product experience arises after consumers have a contact with products directly or indirectly (Hoch, 2002). The third concept is the shopping and experience of service which is happened while a consumer has an interaction with a store's surroundings, its staff, and its rules and routines (Arnould \& Price, 1993). The fourth one is consumption experience which occurs once consumers consume products (Holbrook \& Hirschman, 1982). The last concept is the brand experience. Brand experience defined as "subjective, internal consumer responses (sensations, feelings, and cognitions) and behavioral responses evoked by brand-related stimuli that are part of a brand's design and identity, packaging, communications, and environments" (Brakus et al.,, 2009). Brand experience shaped through a sensory, an affective, a behavioral, and an intellectual-dimensions whenever customers engaged rationally and emotionally with the brand-related stimuli during their shopping, consuming products and services, having interaction with person and shop's physical environment, and through marketing communication. University brand experience can occur due to student interactions with the university brand-related stimuli including university brand's color, design, slogan, mascots, and character.

\section{Loyalty}

Loyalty consists of cognitive, conative and action loyalty. Cognitive loyalty related to experiencebased loyalty, affective loyalty related to pleasurable fulfillment, conative loyalty related to desire to repurchase, and action loyalty related to repeated action. Loyalty refers to "a deeply held commitment to rebuy or re-patronize a preferred product/service consistently in the future, thereby causing repetitive same-brand or same brand-set purchasing, despite situational influences and marketing efforts having the potential to cause switching behavior" (Oliver, 1999)." The psychological process of loyalty consists of behavioral and attitudinal elements which is related to degree of repeat purchase, and attitudinal loyalty associated to devotion on the brand (Chaudhuri \& Holbrook, 2001). By having behavioral loyalty, university students are expected to have the readiness to pay best prices and spread out positive words of mouth. Loyalty is also expected to lead to a favorable manner toward stakeholders and resistant to their competitors. Customers that experience brand-related stimuli such as brand design, identity, marketing communication, and environments in which a brand is marketed can enhance the loyalty toward the brand.

\section{Brand Personality}

Top of mind and unique brand association are important branding paradigm. A brand can represent cultural tension and ideologies, embedded in popular culture and celebrities, deliver mythic meaning, 
entrenched inhabit and rituals and perceived value in the customer's world. Customer buying brands because they involved with the different relationships with the brand from the meaning they add to their lives and reflect external brand promise (Fournier, 1998). Brand personality definition and construct derived from the Big Five Psychology. Brand personality which is defined as "The set of human characteristics associated with a brand," has a symbolic meaning which characterize brand as having human trait (Aaker, 1997). The personality of a brand can support customers to express their self-concept, whether ideal or actual-self, through the utilization of a brand (Malär et al.,, 2011). Therefore, the brand personality that consists of sincerity, excitement, competence, sophistication, and ruggedness traits can be the central driver's customer preference for using the brand.

\section{Satisfaction}

Satisfaction defined as "evaluation of the perceived discrepancy between prior expectations and the actual performance of the product," and customer thought to be satisfied when they perceive fair treatment and when they attribute favorable outcomes to themselves and unfavorable ones to others (Oliver, 1980). Overall customer satisfaction consists of perceived quality as market evaluation to recent customer experience, perceived value as perceived level of product quality relative to price, and customer expectation as prior consumption experience with the firms offering and forecast of supplier ability to deliver quality in the future (Oliver, 1980).

\section{The Effect of Brand Experience on Loyalty}

Loyalty is known as a commitment to repurchase products or services in the future (Oliver, 1999). In a university context, products refer to any kinds of program, creations, inventions, or merchandise produced and labeled as university products, and services refer to any kind of facilities provided by the university. Commitment to repurchase indicates that even though other universities provide the same products or services, even more, attractive ones, students as customers are still devoting university products and services in the future. Furthermore, loyalty can be built through brand experience (Brakus et al.,, 2009). Students who feel good toward brand-related stimuli, including the brand's design and identity, packaging, communications, and environments, will tend to repeat the same experience and become loyal customers. Research conducted by Khan \& Fatma (2017); Sahin et al.,, (2011); and Brakus et al.,, (2009) show that brand experience is significantly positive affects loyalty. Therefore, this study suggests hypothesis as follow:

H1. Brand experience positively affects loyalty.

\section{The Effect of Brand Experience on Brand Personality}

Brand personality refers to human's traits that are considered owned by brand (Aaker, 1997). In the university context, name, design, and symbols owned by university perceived as having human character such as credible, responsible, cheerful, etc. This symbolization can be seen through how the university tried to communicate their identity and build their reputation. Moreover, when students see the personality of the brand fit with their self-concept, they will tend to choose the brand (Malär et al.,, 2011). University brand personality can be developed through customer's experience when they have direct or indirect interaction with the brand-related stimuli. Research performed by Brakus et al.,, (2009) and Keng et al.,, (2013) confirms that brand experience is significantly positive affects brand personality. Therefore, hypothesis derived as follows:

H2. Brand experience positively affects brand personality.

\section{The Effect of Brand Personality on Loyalty}

If university brands can demonstrate and express personality characteristics that congruence with students' self-concept, students as customers will tend to have positive evaluations toward the brand, 
influence their behavioral intention and repurchase behavior, and finally, they will become loyal customers (Sop \& Kozak, 2019). Research that have been done by Sop \& Kozak (2019); Kaushal \& Ali (2019); Han et al.,, (2018); Vera \& Trujillo (2017); Mabkhot et al.,, (2017); Șahin et al.,, (2011) and Brakus et al., (2009) reveals that brand personality is significantly positive affects loyalty. Therefore, the hypothesis formulated as follow:

H3. Brand personality positively affects loyalty.

\section{The Effect of Brand Experience on Loyalty Mediated by Brand Personality}

Refers to the self-verification theory, customers have tendencies to act as the way their self-concept so that they will consume brands that have the same personality with their personality (Malär et al.,, 2011). It means that if university brand personality fit with their self-concept, customers will tend to be loyal customers, and this feeling can be shaped through customers' lifetime experience with the brand-related stimuli. Research conducted by Brakus et al.,, (2009) and Khan \& Fatma (2017) shows that brand experience is significantly positive affects loyalty. In their research, Brakus et al., (2009) and Keng et al.,, (2013) confirms that brand experience is significantly positive affects brand personality. Furthermore, Sop \& Kozak (2019); Kaushal \& Ali (2019); Han et al.,, (2018); Vera \& Trujillo (2017) and Brakus et al.,, (2009) on their research reveals that brand personality is significantly positive affects loyalty. Moreover, research conducted by Brakus et al.,, (2009) and Khan \& Fatma (2017) shows that brand experience is significantly positive affects loyalty. Therefore, hypothesis formed as follow:

H4. Brand personality mediates the effect of brand experience on loyalty.

\section{The Effect of Brand Experience on Satisfaction}

Satisfaction is a former emotion when customers experience a purchase decision (Moreira et al.,, 2017). Because customers have a tendency to seek pleasure experience and avoid boredom, the more experience evokes customers' sensation, feeling, cognition, and behavior, the more customers satisfied with the brand (Brakus et al.,, 2009). Research conducted by Kim et al., (2015) Keng et al., (2013) and Şahin et al., (2011) shows that brand experience is significantly positive affects satisfaction. Therefore, hypothesis suggested as follow:

H5. Brand experience positively affects satisfaction.

\section{The Effect of Satisfaction on Loyalty}

Satisfaction is the determinant of loyalty. By satisfying students, the university is expected to achieve loyalty (Giner \& Rillo, 2016). However, not all satisfied customers will be a loyal customer, but most of the loyal customers must be satisfied (Oliver, 1980; Oliver \& Westbrook, 1993). Research performed by Han et al., (2018), Vera \& Trujillo (2017), Moreira et al., (2017), Giner \& Rillo (2016), Kim et al., (2015), and Şahin et al., (2011) stated that satisfaction is significantly positive affects loyalty. Therefore, hypothesis derived as follows:

H6. Satisfaction positively affects loyalty.

\section{The Effect of Brand Experience on Loyalty Mediated by Satisfaction}

Refers to the theory of planned behavior (Ajzen, 1991), the willingness to behave is motivated by feelings of like or dislike toward behavior. The higher the intention to behave, the higher the possibility to conduct behavior. In the university context, the more students satisfied with the brand evoked by pleasure experience, they will have a tendency to be loyal customers (Brakus et al., 2009). Research conducted by Kim et al., (2015) and Keng et al., (2013) shows that brand experience is significantly positive affects satisfaction. Moreover, research performed by Kim et al., (2015), Moreira et al., (2017), and Giner \& Rillo (2016) stated that satisfaction is significantly positive affects loyalty. In addition, research conducted by Brakus et al., (2009) and Khan \& Fatma (2017) shows that 
brand experience is significantly positive affects loyalty. Therefore, the hypothesis formed as follow: H7. Satisfaction mediates the effect of brand experience on loyalty.

\section{The Effect of Brand Personality on Satisfaction}

Brand personality can create self-expression to helps customers express their self-concept that fit with brand personality. When customers feel fits among their self-concept and brand personality, they will have a positive feeling and evaluation toward the brand and become satisfied with the products and services provided (Keng et al., 2013). Research conducted by Kaushal \& Ali (2019) and Brakus et al., (2009) shows that brand personality is significantly positive affects satisfaction. Therefore, the hypothesis is derived as follow:

H8. Brand personality positively affects satisfaction.

\section{The Effect of Brand Personality on Loyalty Mediated by Satisfaction}

Cognitive learning theories stated that customers learning is based on a model's level of social attractiveness so that they will act to imitated the behavior (Solomon, 2013). If customers see a brand personality resemble their self-concept, they will accumulate their knowledge to behave in the future as the way model behaves. In the university context, the model refers to university brand personality including the person and values that the university has. When they feel favorable toward the brand, they will have a tendency to behaves as the way model behave. The more suitable the brand personality, the more pleased customers will be, and finally, they will have a commitment toward the brand and become loyal customers. Research that has been done by Brakus et al., (2009) and Sop \& Kozak (2019) reveals that brand personality is significantly positive affects loyalty. Furthermore, research conducted by (Brakus et al., 2009) shows that brand personality is significantly positive affects satisfaction. Moreover, research performed by Kim et al., (2015), Moreira et al., (2017), and Giner \& Rillo (2016) stated that satisfaction is significantly positive affects loyalty. Therefore, the hypothesis formulated as follow:

H9. Satisfaction mediates the effect of brand personality on loyalty.

\section{The Effect of Brand Experience on Loyalty mediated by Brand Personality and Satisfaction}

Customers' behaviors are motivated by customers' favorable toward behavior. When they like the behavior they will have a tendency to behave (Solomon, 2013). Refers to self-expansion theory, brand is part of customers' brand identity. Therefore, customers will consume a brand that can represent their self-concept, whether actual or ideal self (Malär et al., 2011). When customers feel enjoy with the brand, they will tend to have positive evaluation toward, and in the long run, this positive feelings will lead to a commitment to repurchase the product or service provided by the brand (Brakus et al., 2009). Studies conducted by Brakus et al., (2009) and Khan \& Fatma (2017) shows that brand experience is significantly positive affects loyalty; Brakus et al., (2009) and Keng et al., (2013) confirms that brand experience is significantly positive affects brand personality; Brakus et al., (2009) shows that brand personality is significantly positive affects satisfaction; and Kim et al., (2015), Moreira et al., (2017), and Giner \& Rillo (2016) stated that satisfaction is significantly positive affects loyalty. Therefore, this study derived hypothesis as follow:

H10. Brand personality and satisfaction mediate the effect of brand experience on loyalty

\section{Methods}

\section{Research Design}

Utilizing the quantitative method, this study examines 1 (one) exogenous variable that is brand experience, 2 (two) mediating variables that are brand personality \& satisfaction, and 1 (endogenous) variables that is loyalty. This research has been conducted in the setting of university branding. 


\section{Data Analysis}

This research population are university stakeholders. Samples of this research are students of a private university in Yogyakarta who experienced university's brand-related stimuli. Purposive random sampling was used as a data sampling technique. Only those who experienced university brand-related stimuli that can be the respondents of this research. We use filter questions to make sure that the respondents were exposed to university brand-related stimuli. As this research perform a selfadministered survey to gather the data, a 5 (five) Likert scale is applied, SEM is being used to analyze the data, and a number of 385 respondents were demanded to fill in the questionnaire.

\section{Operational Definition}

In this research, brand experience is defined as customers' response toward brand-related stimuli, and being measured using 4 brand experience dimension by Brakus et al., (2009). Brand personality is defined as human feature related with the brand, and being measured using 5 factors of brand personality by Aaker (1997). Satisfaction defined as overall evaluation between expectation and actual performance, and being measured using 5 items of satisfaction by Oliver \& Westbrook (1993). Loyalty is defined as commitment to repurchase the same brands which is measured using 5 items of loyalty by Oliver (1999).

\section{Result and Discussion}

\section{Descriptive Analysis}

This study explores the effect of brand experience (BE) on loyalty (L), mediated by brand personality (BP) and satisfaction (S). Refers to Table 1., the data have average value $>3$, which mean that data are homogeneity, the data have standar deviation below 1,0 which means that data have a good distribution and close to the average, BE (mean 4.25, deviation standard 0.714), L (mean 4.05, deviation standard 0.817), BP (mean 4.02, deviation standard 0.708), and S (mean 3.77, deviation standard 0.863). Samples of this study were taken from bachelor and master's degree students of all faculties from a private university in Yogyakarta. A number of 385 students were asked to complete the survey questionnaire, which is consist of 135 males and 250 females (mean 1.65, deviation standard 0,478). There are 169 students below 20 years old, 198 students between 21 to 25 years old, 12 students between 26 to 30 years old and 6 students above 30 years old (mean 4.21, deviation standard 2.304).

Table 1. Descriptive Analysis

\begin{tabular}{|c|c|c|c|c|c|}
\hline & Mean & SD & $\mathrm{BE}$ & BP & $\mathrm{S}$ \\
\hline Gender & 1.65 & 0.478 & & & \\
\hline Age & 4.21 & 2.304 & & & \\
\hline $\mathrm{BE}$ & 4.25 & 0.714 & & & \\
\hline BP & 4.02 & 0.708 & $0.913 *$ & & \\
\hline S & 3.77 & 0.863 & 0.798* & $0.850 *$ & \\
\hline $\mathrm{L}$ & 4.05 & 0.817 & $0.688 *$ & $0.781 *$ & $0.803 *$ \\
\hline
\end{tabular}

\section{Validity and Reliability}

As we can see, based on Figure 1 and Table 2, standardized loading factors of each items whether brand experience, brand personality, satisfaction or loyalty are all above 0.5, and on Figure 2 and Table 2, t-values are all above 1.96, it means that all items are valid, items can be good measurement for the variables. Furthermore, the construct reliability of all variables is higher than 0.7 , and the average variance extracted higher than 0.5 , it means that each of the variables has a good reliability. 
This means that questionnaire has a good consistency and accuracy on measuring each variable in this research.

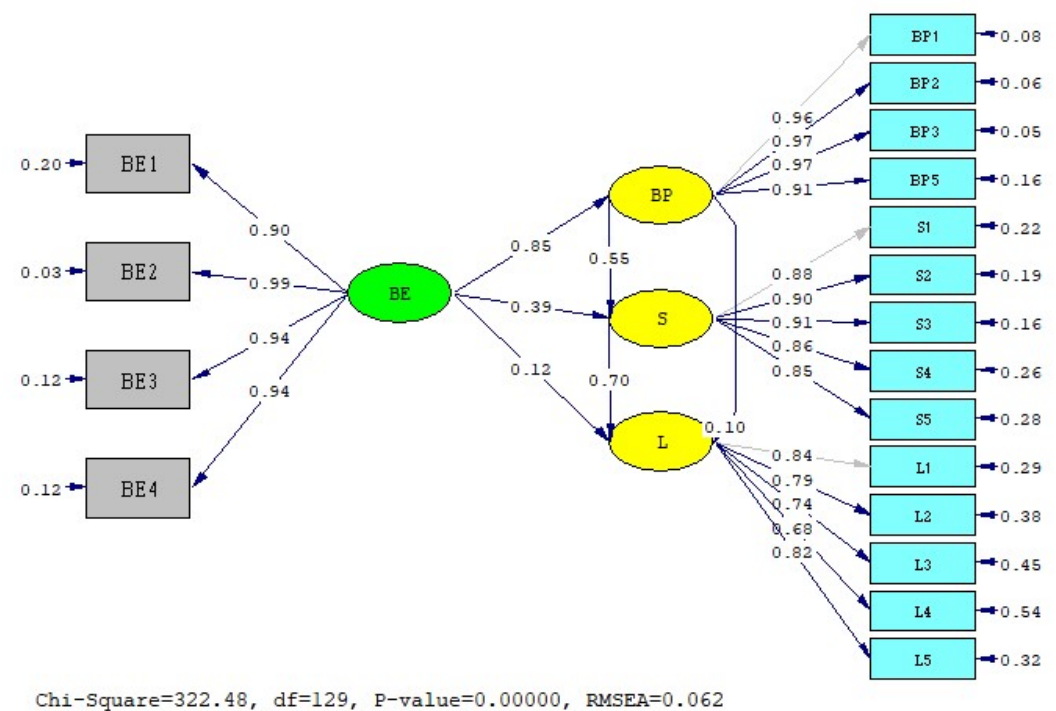

Figure 1. Standardized Loading Factors

\section{Hypothesis testing}

This study proposes and tested ten hypotheses. Decision on the proposed hypotheses is based on Figure 1, Figure 2, and Table 3. Brand experience has no significant and positive impact on loyalty. One of the reasons brand experience is not directly affected loyalty is because the private university is not students' first choice, therefore they might not have good experience toward the brand-related stimuli. It might have different results for state university brand-related stimuli which become the first students' choice. Hence, hypothesis 1 is not supported. Brand experience significantly and positively affects brand personality. This finding is in line with previous study conducted by Brakus et al., (2009) and Kang et al., (2013). University brand personality can be developed through university brandrelated stimuli. This experience can be shaped through students' lifetime interaction with the brand. As a result, hypothesis 2 is supported.

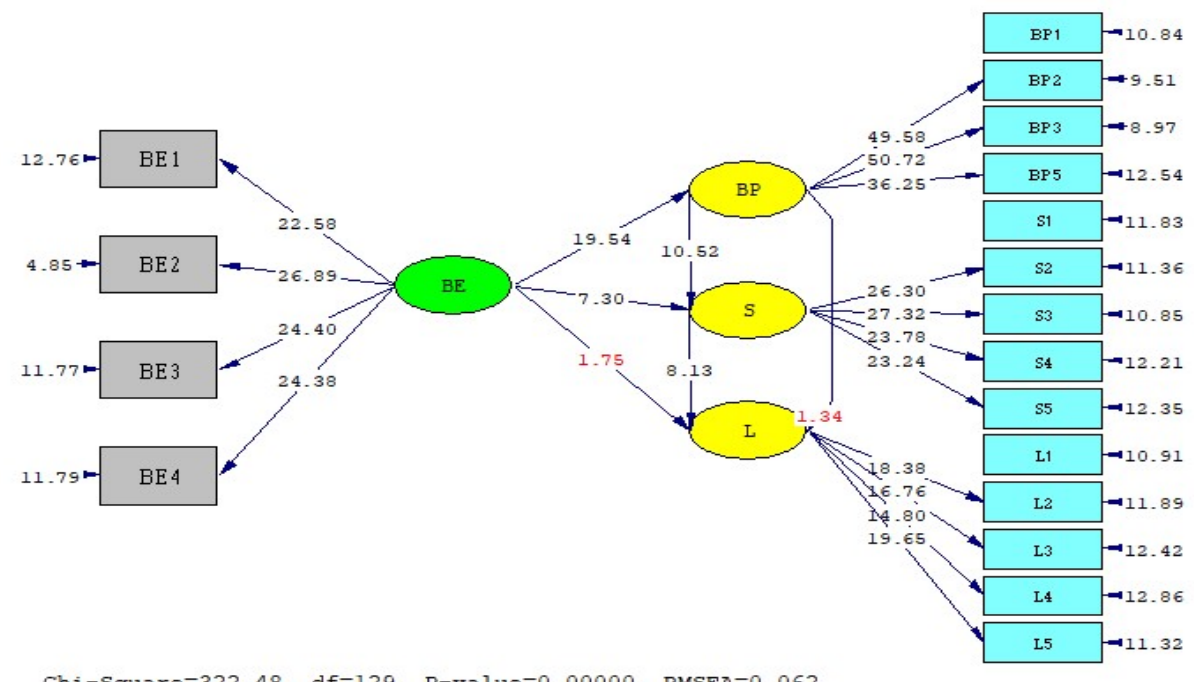

Figure 2. T-value 
In relation to brand personality, the variable has no significant and positive effects on loyalty. The possibility is that the university's brand personality is not strong enough and hence it is also not followed by behaviour. Hence, hypothesis 3 is not supported. Brand personality does not mediate the effect of brand experience on loyalty. This model fits with the self-verification theory which stated that customers tend to act as the way their self-concept, therefore when students find university brand congruence with their self-concept, they will tend to be loyal customers. This congruency can be shaped through customers' lifetime interaction with the brand. Therefore, hypothesis 4 is not supported. Brand experience is significantly and positively affecting satisfaction (Kim et al.,, 2015, Keng et al., 2013, and Şahin et al., 2011). Students tend to seek a favourable experience in the university, therefore when they find it like-able they will tend to be satisfied. Hence, hypothesis 5 is supported.

Table 2. Measurement Model

\begin{tabular}{|c|c|c|c|c|c|}
\hline Observed Variables & $\begin{array}{l}\text { Standardized } \\
\text { Loading Factor }(\geq \\
0.5)\end{array}$ & $\mathrm{R}^{2}$ & $\begin{array}{l}\text { Error } \\
\text { Variance }\end{array}$ & $\begin{array}{l}\text { t-Value } \\
(\geq 1.96)\end{array}$ & Conclusion \\
\hline \multicolumn{6}{|l|}{ BRAND EXPERIENCE } \\
\hline BE1 & 0.90 & 0.81 & 0.20 & 22.58 & \multirow{4}{*}{ Valid } \\
\hline BE2 & 0.99 & 0.98 & 0.03 & 22.89 & \\
\hline BE3 & 0.94 & 0.88 & 0.12 & 24.40 & \\
\hline BE4 & 0.94 & 0.88 & 0.12 & 24.38 & \\
\hline$\sum$ & 3.77 & 3.56 & 0.47 & & \\
\hline Construct Reliability $(\geq 0.7)$ & 0.97 & & & & \multirow{2}{*}{ Reliable } \\
\hline Variance Extracted $(\geq 0.5)$ & 0.88 & & & & \\
\hline \multicolumn{6}{|l|}{ BRAND PERSONALITY } \\
\hline BP1 & 0.96 & 0.92 & 0.08 & 0.00 & \multirow{5}{*}{ Valid } \\
\hline BP2 & 0.97 & 0.94 & 0.06 & 49.58 & \\
\hline BP3 & 0.97 & 0.94 & 0.05 & 50.72 & \\
\hline BP5 & 0.91 & 0.83 & 0.16 & \multirow[t]{2}{*}{36.25} & \\
\hline$\sum$ & 3.81 & 3.63 & 0.35 & & \\
\hline Construct Reliability $(\geq 0.7)$ & 0.98 & & & & \multirow{2}{*}{ Reliable } \\
\hline Variance Extracted $(\geq 0.5)$ & 0.91 & & & & \\
\hline \multicolumn{6}{|l|}{ SATISFACTION } \\
\hline S1 & 0.88 & 0.77 & 0.22 & 0,00 & \multirow{5}{*}{ Valid } \\
\hline S2 & 0.90 & 0.81 & 0.19 & 26.30 & \\
\hline S3 & 0.91 & 0.83 & 0.16 & 27.32 & \\
\hline S4 & 0.96 & 0.92 & 0.26 & 23.78 & \\
\hline S5 & 0.85 & 0.72 & 0.28 & 23.24 & \\
\hline$\sum$ & 4.50 & 4.06 & 1.11 & & \\
\hline Construct Reliability $(\geq 0.7)$ & 0.95 & & & & Reliable \\
\hline Variance Extracted $(\geq 0.5)$ & 0.79 & & & & Reliable \\
\hline \multicolumn{6}{|l|}{ LOYALTY } \\
\hline L1 & 0.84 & 0.71 & 0.29 & 0.00 & \multirow{5}{*}{ Valid } \\
\hline L2 & 0.79 & 0.62 & 0.38 & 18.38 & \\
\hline L3 & 0.74 & 0.55 & 0.45 & 16.76 & \\
\hline L4 & 0.68 & 0.46 & 0.54 & 14.80 & \\
\hline L5 & 0.82 & 0.67 & 0.32 & 19.65 & \\
\hline$\sum$ & 1.50 & 1.13 & 0.86 & & \\
\hline Construct Reliability $(\geq 0.7$ ) & 0.72 & & & & \multirow{2}{*}{ Reliable } \\
\hline Variance Extracted $(\geq 0.5)$ & 0.57 & & & & \\
\hline
\end{tabular}


Table 3. Structural Model

\begin{tabular}{lcccccl}
\hline Hypotheses & $\begin{array}{c}\text { Relationship } \\
\text { Direction }\end{array}$ & $\begin{array}{c}\text { Standardized } \\
\text { Loading Factor } \\
(\geq 0.5)\end{array}$ & $\begin{array}{c}\mathrm{t} \text {-Value } \\
(\geq 1.96)\end{array}$ & Sig. & $\mathrm{R}^{2}$ & Conclusion (Ha) \\
\hline BE - L & $(+)$ & 0.12 & 1.75 & NO & 0.01 & NOT SUPPORTED \\
BE - BP & $(+)$ & 0.85 & 19.54 & YES & 0.72 & SUPPORTED \\
BP - L & $(+)$ & 0.1 & 1.34 & NO & 0.01 & NOT SUPPORTED \\
BE - BP - L & $(+)$ & & & & & NO MEDIATION \\
BE - S & $(+)$ & 0.39 & 7.3 & YES & 0.15 & SUPPORTED \\
S - L & $(+)$ & 0.7 & 8.13 & YES & 0.49 & SUPPORTED \\
BE - S - L & $(+)$ & & & & & FULLY MEDIATED \\
BP - S & $(+)$ & 0.55 & 10.52 & YES & 0.30 & SUPPORTED \\
BP - S - L & $(+)$ & & & & & SUPPORTED \\
BE - BP - S - L & $(+)$ & & & & & FULLY MEDIATED \\
\hline
\end{tabular}

Satisfaction is significantly and positively affect loyalty, the result consistent with previous studies such as Han et al., (2018), Moreira et al., (2017), Giner \& Rillo (2016) and Vera \& Trujillo (2017). When students experience positive feeling on university, they tend to be loyal. As a result, hypothesis 6 is supported. In the meantime, satisfaction is fully mediating the effect of brand experience on loyalty. This result in line with the theory of planned behaviour. When customers feelgood experience, they tend to be satisfied. Satisfaction will lead to loyalty. Hence, hypothesis 7 is supported. Brand personality is significantly positive affects satisfaction (Kaushal \& Ali, 2019 and Brakus et al.,, 2009). When customers feel fit among their self-concept and brand personality, they will have a positive evaluation of the brand. Hence, hypothesis 8 is supported.

Satisfaction mediates the effect of brand personality on loyalty. This is in line with the cognitive learning theory. If students see a brand personality resemble their self-concept, they will accumulate their knowledge to behave in the future as the way model behaves. Therefore, hypothesis 9 is supported. Lastly, brand personality and satisfaction mediate the effect of brand experience on loyalty. Consumers behaviour is motivated by customers' favourable toward behaviour. In line with the self-expansion theory, a brand is part of customers' brand identity. Therefore, customers will consume a brand that can represent their self-concept, whether actual or ideal self. When customers feel enjoy with the brand, they will tend to have positive evaluation toward, and in the long run, this positive feeling will lead to a commitment to repurchase the product or service provided by the brand. As a result, hypothesis 10 is also supported.

\section{GOF Index}

Finally, based on Table 3, we can see that this model is having a good fit model. The degree of freedom is 129 , chi-square 322.48 , RMSEA 0.062, CFI 0.99, and GFI 0.99. This means that the set of parameters used in this research is good for defining the problem in this study.

Table 4. Goodness of Fit Index

\begin{tabular}{ccccccc}
\hline $\begin{array}{c}\text { Degree of } \\
\text { Freedom }\end{array}$ & $\begin{array}{c}\text { Chi- } \\
\text { Square } \\
\left(\mathrm{X}^{2}\right)\end{array}$ & $\begin{array}{c}\text { Sig. } \rho \\
(>0.05)\end{array}$ & $\begin{array}{c}(0.08 \geq \text { RMSEA } \geq 0.05) \\
\text { CFI }\end{array}$ & $\begin{array}{c}\text { GFI } \geq 0.90) \\
(\geq 0.90)\end{array}$ & Conclusion \\
\hline 129 & 322.48 & 0.00 & 0.062 & 0.99 & 0.91 & GOOD FIT \\
\hline
\end{tabular}




\section{Conclusion}

This study aims to investigate the determinants of loyalty toward the university. Results show that three of ten hypotheses are not supported. Students who experience brand-related stimuli such as brand design, identity, marketing communication, and environments in which a brand is marketed are not directly a loyal customer, so does those who feel that the brand can represent students personality or self-concept, however, when the brand can provide them with pleasant feeling \& avoid boredom, students will tend to have positive evaluation toward the brand and will be loyal toward the brand. When students experience brand-related stimuli, the brand represents their personality or self-concept and giving students pleasant feelings, students will tend to be a loyal customer. This study implies that universities should improve students' satisfaction to gain loyalty, and consider university brand experience and brand personality to strengthen students' satisfaction toward the university. Future studies should address the area of service experience as a university classified as a service organization and to have comparative studies among private and public universities.

\section{Acknowledgments}

We would like to thank you to Lembaga Penelitian dan Pengabdian Masyarakat (LP3M) Universitas Sarjanawiyata Tamansiswa (UST) for funding this research.

\section{References}

Aaker, J. L. (1997). Dimensions of brand personality. Journal of Marketing Research, 34(3), 347-356. https://doi.org/10.2307/3151897

Ajzen, I. (1991). The theory of planned behavior. Organizational Behavior and Human Decision Processes, 50(2), 179-211. https://doi.org/10.1016/0749-5978(91)90020

Aula, H.-M., \& Tienari, J. (2011). Becoming “world-class”? reputation-building in University merger. Critical Perspectives on International Business, 7(1), 7-29. https://doi.org/10.1108/17422041111103813

Arnould, E. J., \& Price, L. L. (1993). River magic: Extraordinary experience and the service encounter. Journal of Consumer Research, 20(1), 24. https://doi.org/10.1086/209331

Baker, M. J., \& Balmer, J. M. T. (1997). Visual identity: trappings or substance? European Journal of Marketing, 31(5/6), 366-382. https://doi.org/10.1108/eb060637

Balaji, M. S., Roy, S. K., \& Sadeque, S. (2016). Antecedents and consequences of university brand identification. Journal of Business Research, 69(8), 3023-3032. https://doi.org/10.1016/j.jbusres.2016.01.017

Balmer, J. M. T., \& Liao, M. N. (2007). Student corporate brand identification: An exploratory case study. Corporate Communications, 356-375. https://doi.org/10.1108/13563280710832515

Bennett, R., \& Ali-Choudhury, R. (2009). Prospective students' perceptions of University Brands: An empirical study. Journal of Marketing for Higher Education, 19(1), 85-107. https://doi.org/10.1080/08841240902905445

Brakus, J. J., Schmitt, B. H., \& Zarantonello, L. (2009). Brand experience: What is it? how is it measured? does it affect loyalty? Journal of Marketing, 73(3), 52-68. https://doi.org/10.1509/jmkg.73.3.52

Brewer, A., \& Zhao, J. (2010). The impact of a pathway college on reputation and brand awareness for its affiliated University in Sydney. International Journal of Educational Management, 24(1), 34-47. https://doi.org/10.1108/09513541011013033 
Chaudhuri, A., \& Holbrook, M. B. (2001). The chain of effects from brand trust and brand affect to brand performance: The role of brand loyalty. Journal of Marketing, 65(2), 81-93. https://doi.org/10.1509/jmkg.65.2.81.18255

Fazli-Salehi, R., Esfidani, M. R., Torres, I. M., \& Zúñiga, M. A. (2019). Antecedents of students' identification with university brands: A study on public universities in Iran. Asia Pacific Journal of Marketing and Logistics, 31(4), 830-854. https://doi.org/10.1108/APJML-072018-0242

Foroudi, P., Dinnie, K., Kitchen, P. J., Melewar, T. C., \& Foroudi, M. M. (2017). IMC antecedents and the consequences of planned brand identity in higher education. European Journal of Marketing, 51(3), 528-550. https://doi.org/10.1108/EJM-08-2015-0527

Fournier, S. (1998). Consumers and their brands: Developing relationships theory in consumer research. Journal of Consumer Research, 24(4), 343-353. https://doi.org/10.1086/209515

Giner, G. R., \& Rillo, A. P. (2016). Structural equation modeling of co-creation and its influence on the student's satisfaction and loyalty towards University. Journal of Computational and Applied Mathematics, 291, 257-263. https://doi.org/10.1016/j.cam.2015.02.044

Goi, M. T., Goi, C. L., \& Wong, D. (2014). Constructing a brand identity scale for higher education institutions. Journal of Marketing for Higher Education, 24(1), 59-74. https://doi.org/10.1080/08841241.2014.906017

Han, H., Nguyen, H. N., Song, H., Chua, B.-L., Lee, S., \& Kim, W. (2018). Drivers of brand loyalty in the chain coffee shop industry. International Journal of Hospitality Management, 72(December 2017), 86-97. https://doi.org/10.1016/j.ijhm.2017.12.011

Heffernan, T., Wilkins, S., \& Butt, M. M. (2018). Transnational higher education: The importance of institutional reputation, trust and student-university identification in international partnerships. International Journal of Educational Management, 32(2), 227-240. https://doi.org/10.1108/IJEM-05-2017-0122

Herrero-Crespo, Á., Gutiérrez, H. S. M., Herrero-Crespo, Á., Gutiérrez, H. S. M., \& Salmones, M. G.D. los. (2016). Influence of country image on country brand equity: Application to higher education services. In International Marketing Review (Vol. 33, Issue 5). https://doi.org/10.1108/IMR-02-2015-0028

Hoch, S. J. (2002). Product experience is seductive. Journal of Consumer Research, 29(3), 448-454. https://doi.org/10.1086/344422

Holbrook, M. B., \& Hirschman, E. C. (1982). The experiental aspects of consumption: Consumer fantasies, feelings, and fun. Journal of Consumer Research, 9(2), 132. https://doi.org/10.1086/208906

Kantanen, H. (2012). Identity, image and stakeholder dialogue. Corporate Communications, 17(1), 56-72. https://doi.org/10.1108/13563281211196353

Kaushal, V., \& Ali, N. (2019). University reputation, brand attachment and brand personality as antecedents of student loyalty: A study in higher education context. Corporate Reputation Review. https://doi.org/10.1057/s41299-019-00084

Keng, C.-J., Tran, V.-D., \& Thi, T. M. Le. (2013). Relationships among brand experience, brand personality, and customer experiental value. Contemporary Management Research, 9(3), 247-262. https://doi.org/10.7903/cmr.11086

Khan, I., \& Fatma, M. (2017). Antecedents and outcomes of brand experience: An empirical study. Journal of Brand Management, 24(5), 439-452. https://doi.org/10.1057/s41262-017-0040-x 
Khanna, M., Jacob, I., \& Yadav, N. (2014). Identifying and analyzing touchpoints for building a higher education brand. Journal of Marketing for Higher Education, 24(1), 122-143. https://doi.org/10.1080/08841241.2014.920460

Kim, C. K., Han, D., \& Park, S. (2001). The effect of brand personality and brand identification on brand loyalty. Japanese Psychological Research, 43(4), 195-206.

Kim, J. W., Lee, F., \& Suh, Y. G. (2015). Satisfaction and loyalty from shopping mall experience and brand personality. Services Marketing Quarterly, 36(1), 62-76. https://doi.org/10.1080/15332969.2015.976523

Mabkhot, H. A., Shaari, H., \& Salleh, S. M. (2017). The influence of brand image and brand personality on brand loyalty, mediating by brand trust: An empirical study. Jurnal Pengurusan, 50, 71-82. https://doi.org/10.17576/pengurusan-2017-50-07

Malär, L., Krohmer, H., Hoyer, W. D., \& Nyffenegger, B. (2011). Emotional brand attachment and brand personality: The relative importance of the actual and the ideal self. Journal of Marketing, 75(4), 35-52. https://doi.org/10.1509/jmkg.75.4.35

Moreira, A. C., Da Silva, P. M. F., \& Ferreira Moutinho, V. M. (2017). The effects of brand experiences on quality, satisfaction and loyalty: An emperical study in the telecommunications multipleplay service market. Revista Innovar Journal, 27(64), 23-38. https://doi.org/10.15446/innovar.v27n64.62366

Mourad, M., Ennew, C., \& Kortam, W. (2011). Brand equity in higher education. Marketing Intelligence \& Planning, 29(4), 403-420. https://doi.org/10.1108/02634501111138563

Oliver, R. L. (1980). A Cognitive Model of the Antecedents and Consequences of Satisfaction Decisions. Journal of Marketing Research, 17(4), 460-469. https://doi.org/10.2307/3150499

Oliver, R. L. (1999). Whence Consumer Loyalty. Journal of Marketing, 63, 33-34. https://doi.org/10.2307/1252099

Oliver, R. L., \& Westbrook, R. A. (1993). Profiles of consumer emotions and satisfaction in ownership and usage. Journal of Consumer Satisfaction, Dissatisfaction and Complaining Behavior, 6, $12-27$.

Pinar, M., Trapp, P., Girard, T., \& Boyt, T. E. (2011). Utilizing the brand ecosystem framework in designing branding strategies for higher education. International Journal of Educational Management, 25(7), 724-739. https://doi.org/10.1108/09513541111172126

Pinar, M., Trapp, P., Girard, T., \& Boyt, T. E. (2014). University brand equity: An empirical investigation of its dimensions. International Journal of Educational Management, 28(6), 616-634. https://doi.org/10.1108/IJEM-04-2013-0051

Pinna, R., Carrus, P. P., Musso, M., \& Cicotto, G. (2018). The effects of students: University identification on student's extra role behaviours and turnover intention. TQM Journal, 30(5), 458-475. https://doi.org/10.1108/TQM-11-2017-0153

Plewa, C., Ho, J., Conduit, J., \& Karpen, I. O. (2016). Reputation in higher education: A fuzzy set analysis of resource configurations. Journal of Business Research, 69(8), 3087-3095. https://doi.org/10.1016/j.jbusres.2016.01.024

Sahin, A., Zehir, C., \& Kitapçı, H. (2011). The effects of brand experiences, trust and satisfaction on building brand loyalty; An empirical research on global brands. Procedia - Social and Behavioral Sciences, 24, 1288-1301. https://doi.org/10.1016/j.sbspro.2011.09.143

Schmitt, B. (1999). Experiential Marketing. Journal of Marketing Management, 15, 53-67. 
https://doi.org/10.1362/026725799784870496

Solomon, M. R. (2013). Consumer behavior: Buying, having and being (10ed). Boston: Pearson Education.

Sop, S. A., \& Kozak, N. (2019). Effects of brand personality, self-congruity and functional congruity on Hotel brand loyalty. Journal of Hospitality Marketing and Management, 28(8), 926-956. https://doi.org/10.1080/19368623.2019.1577202

Stephenson, A. L., \& Yerger, D. B. (2014). Optimizing engagement: Brand identification and alumni donation behaviors. International Journal of Educational Management, 28(6), 765-778. https://doi.org/10.1108/IJEM-04-2013-0057

Vera, J., \& Trujillo, A. (2017). Searching most influential variables to brand loyalty measurements: An exploratory study. Contaduria y Administracion, 62(2), 600-624. https://doi.org/10.1016/j.cya.2016.04.007

Williams, R. L., \& Omar, M. (2014). How branding process activities impact brand equity within Higher Education Institutions. Journal of Marketing for Higher Education, 24(1), 1-10. https://doi.org/10.1080/08841241.2014.920567 